\title{
On the separation of the Moldavian estates after the Bucharest Peace (1812). Several additions ${ }^{\dagger}$
}

\author{
Petronel Zahariuc* \\ Faculty of History, "Alexandru Ioan Cuza" University, Bd. Carol I 11, 700506 Iași, Romania
}

\section{Article info \\ History: \\ Received September 8, 2018 \\ Accepted September 13, 2018 \\ Published May 7, 2019}

Key words:

Moldova

Bessarabia

Bucharest Peace

1812

villages

small towns

\begin{abstract}
After the occupation of Moldavia between the Pruth and the Dniester, the Russian Empire imposed, through the Bucharest peace, to the estate owners to choose within 18 months the country side where they would live. For a while, the Romanians believed that the Russian army would retreat, like it happened beforehand, so they postponed making a decision until the fall of 1813 , when they had to "separate" themselves from the estates to the left or to the right of the Pruth. Most of the great landowners chose to stay in Moldavia under Ottoman domination. Hence, proportionally, most of the estates sold were on the side of the country occupied by the Russian Empire. The way this process unfolded was reconstructed by Alexandru Lapedatu (1916), and the current paper brings a series of additions and clarifications, as well as a list, unpublished and unused in the Romanian historiography, with 387 villages and parts of villages, from Moldavia left from the Pruth, sold or changed in the last two months of the year 1813 and in the first days of the year 1814. At the same time, this paper suggests, at a general level, the way the separation of estates and families led to the separation of Moldavia, but, at the same time, secondarily, this multitude of names of settlements and masters may be used, sometime in the future, to the elaboration of a historical and toponymic study of the localities from the left of the Pruth, following the model of the one elaborated for the localities on the right bank of the Pruth by the toponymy collective with the "A. Philippide" Romanian Philology Institute, coordinated by Prof. Dragoș Moldovanu.
\end{abstract}

\section{Introduction}

Upon analyzing the historical bibliography of Bessarabia, I noticed that in the last few years, there have been many discussions on the aspects before, during and after the year 1812, concerning Bessarabia, the entire Moldavia and the entire Eastern Europe. This small contribution does not claim such comprehensiveness, but it only wishes to be an attempt for analyzing why the free villagers and the monks separated from or held on to their estates, to their land, when the country's land was divided. Their land, the limits of their villages were their only reality, while the great border of the country was a rare sight, partly due to incompetent rulers, recruited among them or among foreigners, partly because the mindset of the time did not allow them to see it - only their children and grandchildren would get to see it better, and when they see it and understand it, they will weep. Is it still the case today?

Quite a while ago, not now, when two centuries had passed from the determination of the first border along the Pruth, thus separating the estates and what had been left from the country's land in two, long ago, several years after I understood that the Pruth could lose its bad reputation, of border between Romanians, I started collecting from various archives on the right side of the river documents and other brief accounts, in order to understand how the Romanians understood what had happened to them and to their country in 1812. Of course, small things are not enough to get a picture, because most of the times historical

${ }^{\dagger}$ This study is part of the outcomes of the following research project: UEFISCDI, PN-III-P4-ID-PCE-2016-0557.

*Email address:zahariuc@uaic.ro. 
life is elsewhere, to paraphrase the title of a famous novel by Milan Kundera, namely in deeds and great historical places: wars and capitals, heroes and peace treaties, acts of bravery and villainous treasons. All of the above were merged in 1812 and much has been written about them and will be written for a long time, both good and bad. Fewer, but quality things have been written by the boyars and their estates, mostly on the occasion of the $100^{\text {th }}$ commemoration of the loss of Bessarabia (Iorga, 1912a; Lapedatu, 1916), while little has been written about monasteries and their estates. The scarcity of these studies is due both to the relatively small importance of the topic, and to the lack of systematic archive research, which led to the absence of themed collections of internal documents, to comprise the year 1812 and the subsequent years ${ }^{1}$. To them, it is worth adding the brutal injunction of politics in historical research, occurred in Kishinev, Iaşi and Bucharest after the Second World War. Besides some documents published by interwar historians (Aurel Sava, Constantin Tomescu, Leon Boga, Ştefan Berechet, Gheorghe Ghibănescu and others), here and there, and the histories of certain cities and villages and the histories of certain families, several documents "sieved", accounting for the way owners separated themselves from their possessions, both in the period 1812-1814, and in the subsequent years.

After the radical changes in Eastern Europe occurred in the late 1980s, the research on the 1812 moment also emerged and multiplied significantly, and the daily life of people could not escape the historian's insightful eyes. This historian, this time in this field, too, circumscribed to the tiresome archive research, belongs to the academia and higher education environment in the Republic of Moldova and to a lower extent (or at all) to the scientific environment in Romania, interested mainly in highlighting the great directions of the Romanian historical life, one of them being the general history of the Romanian space between the Pruth and the Dniester and even a little beyond. Among the historians in Bessarabiaattached to the research of the historical beginnings of this side of Romanian country, become a Russian province-I remind Dinu Poștarencu (2006) and mostly Valentin Tomuleț (2007; with the bibliography of the author's works), a thorough and valuable account of the Bessarabian social life in the first decades after the annexation, from an old lineage of Moldavian boyars, which he does not hesitate-reaching the peak of historical impartiality - to scold for the attitude, not always friendly, towards the working villagers on their side of the estates (Tomuleț, 2007, p. 159-178)2.

\section{The separation of Moldavian estates from the left and right banks of the Pruth}

Concerning the years 1812-1814, the relation between boyars and their estates was governed by Article VII of the Bucharest Peace, which stated that the Ottoman (Moldavian) subjects found when war was declared in Bessarabia or settled there during the hostilities to be able to retreat and to settle, if they wish, on the other side of the Pruth, being free to separate their assets and to emigrate with whatever they want to take within 18 months from the ratification of the treaty. Likewise, the boyars born on the left bank of the Pruth, but residing in other parts of the Ottoman Empire, could stay where they were, thus separating themselves from their Bessarabian estates, or they could return home, after selling their assets on the right bank of the Pruth and returning with usually small amount of money, seldom greater amounts (Manucbey may be such an example), in Kishinev or in other places to start a new life under the new ruler, this time around Orthodox (ADIRR, p. 299). This provision was meant to break the political and economic relations between the two parts of Moldavia situated on the middle and lower stream of the Pruth and it seems inspired-if we did not know that all empires adopt this measure when they dismount on the bank of a new river-from the measures adopted in the third part of the country, on the upper stream of the Pruth, torn apart one generation before from the country's body, after similar circumstances, where all the ingredients of diplomacy - ugly for the defeated and blessed for the winners-were fully experienced.

\footnotetext{
${ }^{1}$ Recently, many documents from the period of the Russian occupation (1806-1812) were published and even republished: Doc. Mold. (2012); Doc. T. Mold. (2017).

${ }^{2}$ For the conflict between the inhabitants of the Lăpuşna small town and the boyar Iordache Tomuleț, see also Sava (1935a, 1935b).
} 
The very short term ("interval”) for option, one year and a half (until January $2^{\text {nd }}, 1814$ ), "looked like an expropriation” (Iorga, 1938, p. 204), given that numerous people and estates had to define their status.

In order to prevent some-few, actually - from making a connection between the limit of their estate and the border of the country, between selling their family home and losing their country, the Russians, through general Harting, hid the provision of point VII. A son-in-law of a Moldavian boyar (Bezviconi, 1936, p. 16-109); the Russian general or someone else in his suite failed to keep this important point a secret for long. This point touched one of the important milestones of the road-still foggy-leading to the conscience of distinct ethnic and religious group and to patriotism. Hence, almost immediately, a great delegation of deputies-led by two of the greatest boyars of a country wish small political men, the great chancellor Constantin Balş and Costache Ghica-left for Bucharest to have the war tasks mitigated and to discuss the issue of the estates on the other bank of the Pruth, seeking to obtain for the owners at least the rights they had benefited from after losing Bukovina (Rosetti, 1909, p. 37-38). I believe that for many of the great boyars, the incommensurable wealth gathered by one of them-Iordache Rosetti Roznovanu, precisely due to such a deal with exchanges of "Austrian and Turkish" estates, as they were called-was a reference point, and the context in which he obtained it could be repeated. The Moldavian delegation solved nothing from this perspective, while concerning the first, the Russians had mercy and they reduced some of the burdens for Moldavia, in both cash and kind.

Seeing that the new master is deaf, though the same songs were chanted in churches, sometimes singing the same words, the boyars resigned themselves and they only made attempts to remind the former master - the Ottoman Empire, which became ruthless and indifferent - through the loyal and feeble servant sent as "bey" but claiming to be prince, namely Scarlat Calimachi, that their food and the food for the capital of the rest of Moldavia, Iaşi, no longer come from the other side of the Pruth, and famine was just around the corner (Iorga, 1912b, p. 157-158). The tough economic measures adopted by the Russian administration on the left bank of the Pruth had a mainly political purpose, namely to divert the attention of the Moldavian boyars from the serious long-term issues of the country towards small problems concerning daily survival. In this context, the application of the $7^{\text {th }}$ point of the peace treaty became pressing, because the situation of the estates on the other side of the Pruth got worse and worse. The great landowners who resided in Iaşi had to solve the great dilemma and, first of all, to choose on which side of the river they want to live and thus, to which mansions they have to give up. Nonetheless, though the provisions of the treaty proved to be implacable, they were not as such for the contemporaries, who still hoped things would turn for the better; that something good would happen to make the country whole again and to preserve the family heritage intact. Such hope was to no avail, even for the contemporaries, who had the example of Bukovina close by; they even began learning to pronounce its name.

The hope and rumours from Napoleon's campaign in Russia prolonged the moment set to make a choice (Casso, 1940; Goșu, 2008), thus, for a few months, until late 1812, only a few estates had been sold or exchanged. Furthermore, some of them were apparently estranged, according to Catinca Ghica, after the exchange made with her father-in-law, the treasurer Iordache Rosetti, to whom she gave her dowry estates on the other side of the Pruth and he received several of his estates "on this side of the Pruth, from the regions of Neamț, Bacău, Putna, Botoșani, Hîrlău, Vaslui and the houses in Iași and vineyards”. Here is what the owner's wife had to say: "I have hereby confirmed that this exchange has been made only with 'economy', thus it has no legal grounds, no power, because no legal documents were signed; there were only letters from my father-in-law, the treasurer; thus, such exchange is not valid; it is just a blank paper" (ANI, Doc., 143/70; November $\left.12^{\text {th }}, 1812\right)^{3}$. At the same time, the elite kept on writing reports, meant to extend the term for deciding where to live in the future, where they complained that it was hard to find profitable solutions for selling the estates, and that it was sad to separate families into two branches, on the right and on the left of the Pruth. "We think of the fact that we will leave our ancestors' land, that we will divide

\footnotetext{
${ }^{3}$ Another sales contract, made with "economy", is the one through which the căminar Anastase Scorțăscu would have sold to the căminar several meters of the Măgureli estate, in the region of Iași, for which on December 29 ${ }^{\text {th }}, 1813$, the buyer admits that he "did not buy them or pay nothing for them" (BAR, Doc. ist., CXXI/199).
} 
our wealth and separate sons from parents, siblings and other relatives; some of us choose to leave on the other side of the Pruth, while others to remain on the estates here" (Lapedatu, 1916, p. 8). Besides reports, also benefiting from the experience of the Committee instituted by the Russians, in $1808^{4}$, to research the claims for the Moldavian estates taken by the Turks when they formed the raya of Hotin (1715), the great boyars founded a "Committee on the separation of the estates on the other side of the Pruth" (Iorga, 1995, p. 289). Their duty was to study and approve the sales and exchange contracts to be concluded and to judge the litigations to emerge after certain businesses. From this Committee, the documents arrived to the country's Divan. Then, for authentication, they were sent to the Russian Consulate in Iaşi, and finally to Department I of Bessarabia, from where owners obtained documents of continual property of the assets bought or exchanged.

With all this apparent lack of organization, chaos was the word that characterized the best the situation of Moldavia, and this state of spirit was the most accurately depicted by Manolachi Drăghici, in words often quoted from the moment they were written to this day, reason for which I will outline them again. "The Moldavian inhabitants believed for a long time that the Bucharest Peace was temporary and they waited every day to get back the land taken by the Russians and to restore the borders of their country, as they used to be, but they deluded themselves because they thought such status would help their particular interests, because they did not hurry to take energetic measures for the separation of the immovable wealth on the left bank of the Pruth, until the term arrived. At that point, they walked around full of confusion, not knowing what to do: some of those under Russian protection let go of it; some of those decided to remain in Moldavia said nothing and they concealed their actions to prevent from saying anything until the hour of the Pruth closure, in order to decide at the last moment what to do. But when the fatal day of Convention expiry came, after the treaty, when everyone had to decide where to live definitively, complaints poured, because people came in flocks on the bank of the Pruth, from one end to another, coming and going from villages and from small towns for weeks, saying goodbye from their parents, from their siblings and their relatives, with whom they had grown up and lived until time came to part ways forever" (Drăghici, 2017, p. 202-203).

People were indeed disoriented; many of them choosing the right bank of the Pruth, but their leaders did not leave the resolution of their heritage status for the last minute. Thus, after they failed in early November 1813 to obtain a postponement of the term stipulated by "the decision of the holy treaties concluded in Bucharest, in the year 1812, between the powerful kingdoms of Russia and the Ottoman Porte" ${ }^{15}$, the Metropolis of Moldavia and Suceava, the monasteries and the boyars increased the rhythm of the sales and exchanges of estates situated on one side and the other of the Pruth. Because few of the great landowners chose to live on the left bank of the Pruth and the Russian authorities founded a new ecclesiastical structure in the occupied territory, most real estate transactions concerned small towns, villages and parts of villages within the regions taken. Of course, there are also reverse transactions, but far more modest, where the selling or exchanging party-mostly among the "low boyars" (Iorga, 1938, p. 205) - had to choose to live as subjects of the Russian tsar. Very few of the low boyars, whose estates were on the left of the Pruth, had other estate parts on the right bank ${ }^{6}$. A more common case is the one of a boyar's daughter married to some officer within the Russian army, who settled on the other side of the Pruth, in Kishinev or even farther, in Russia, and who sold the dowry from the parents 7

\footnotetext{
${ }^{4}$ Some of the documents resulted from the activity of this committee are stored in the archives of Iași, and some of those were used by my colleague Gumenâi (2002).

${ }^{5} \mathrm{~A}$ formula within the sales and purchase document, dated December $30^{\text {th }}, 1813$ (ANI, Doc., 215/8). In other documents, the phrase "holy treaties" is replaced by "high treaties" (see for instance the document of December 16 ${ }^{\text {th }}, 1813$; Lapedatu, 1916, p. 32, no. 12).

${ }^{6}$ Among them, Andrei Milu, who chose to settle on the right bank of the Pruth and sold to Constantin Catargi spatharus, on December $28^{\text {th }}, 1813$, the Muncel estate, in the region of Roman (ANI, 0, 407/74).

${ }^{7}$ On June $26^{\text {th }}, 1812$, Caterina, the daughter of the deceased boyar Grigoraș Bașotă former high spatharus, the wife of Alexei Bolgovscoi the polcovnic, "upon deciding to relocate to Russia alongside my husband", she sold 20 houses of Gypsies (70 people in total), to an association comprising the spatharus Alecu Greceanul, the cupbearer Tudurachi Ciure and the sulger
} 
On the contrary, sales and purchase documents and exchange documents of the particulars and institutions that preserved their residences where they were are much more numerous and some of them were even published ${ }^{8}$, some others not, some discovered, some others not, all pertaining to the last two months at the end of the year 1813. One of the first major exchange and sales documents was drafted up by metropolitan Veniamin Costachi, on November $18^{\text {th }}$, 1813, and by Alexandru Anastase former great serdar, through which the first gave some estates of the Metropolis and an estate of the monastery of Pîngărați on the other side of the Pruth and he received the estates on this side of the Pruth of the serdar, along with the amount of Lei 62,000 (Lapedatu, 1916, p. 26-27, no. 7) ${ }^{9}$. From the estates on the other side of the Pruth, a part of the domestic monasteries were also separated, while all the monasteries dedicated to the Holy Land, after a moment of confusion, when they hasted and started to sell their possessions (Lapedatu, 1916, p. 26-27, issue 8; the report of general Harting to the tsar, of December $7^{\text {th }}, 1813$ ), were advised to return, being allowed to keep managing them (Cazacu, 1992, p. 129). The differential treatment granted to the monasteries of Moldavia remained under Ottoman domination, mostly of those dedicated to establishments in the south of the Danube, constituted a bait thrown by the Orthodox power in the North for the clergy and the Orthodox believers in Moldavia and in the Balkans, which provided results only for the latter (Niță-Danielescu, 2017, p. 393).

However, the particulars who were clearly defined under Article VII of the Bucharest treaty were forced to obey; hence, they had to find in a terribly short time- the threat of the plague did not help ${ }^{10}$ ways to save through sales or exchange documents (true or false) something of the correct price of real estate wealth within the regions on the other side of the Pruth. Thus, from November 1813 to early January 1814, to the right and to the left of the Pruth there was a generalized "real estate fair", all inclusive: winners and losers, good prices and mostly bargains, newly enriched and newly pauperized, tears and shouts of joy, briefly and coldly collected in the list of "the document of the estates bought in the region of Bessarabia, comprising the names of villages and the region they pertain to, and the name of sellers and buyers", of February 1814, which I publish here (see the Annex).

The list as it was preserved comprises 387 villages and parts of villages, disseminated in all the regions of Moldavia from the left of the Pruth. The abrupt end of the six-page "notebook" preserved seems to show that the list had one or maybe two more pages, lost since, which would mean there are still a couple dozen settlements. The fact that the list may have had a couple extra pages is also proven by a series of published documents, comprising villages that are not included in the document preserved. Anyway, the list preserved comprises half of the villages within the region of Bessarabia, if we consider the number of 685 villages and 17 small towns, provided by Ion Nistor (1991, p. 179) ${ }^{11}$. Besides the list, should their

Ianachi Adam, for Lei 15,459. It is interesting that the occupations of the Gypsies show who had to do the jobs on a noble estate, because they included: a tailor, a belt-maker, two shoemakers, two coachmen, a blacksmith, a furrier, a baker, three violinists and a cook (ANI, Doc., 344/73). On September 30 th 1812 , Caterina sold the estate of Vlădeni, in the region of Hîrlău, for the same reason, with 30 villagers, a church, a bar and an eating place to Iordache Catargiu former high spatharus, for Lei 60,050 (Lapedatu, 1916, p. 18-20, no. 1, 2). For the scandalous life of Ecaterina, who was, among others, the lover of the poet Pushkin, see the note of Mihai Dim. Sturdza (2004, p. 378). Then, on January $1^{\text {st }}, 1814$, mayor Costandin Șainovici and his wife, Despina, the daughter of Tănase the infantry captain, sell to Mihalache Mavrogheni chamberlain a part of the dowry estate of Despina, Oroftiana, in the region of Herța, for Lei 6,000 (ANI, Doc., 462/51). Mayor Șainovici built a house in Kishinev (Sava, 1933, p. 678-679).

${ }^{8}$ The largest group of documents was published by Lapedatu ( 28 documents, dated from September $29^{\text {th }}, 1812$ to May $23^{\text {rd }}, 1814 ; 1916$, p. 15-48). In addition, an interesting document, through which Ioniță Bașotă, settled in Bessarabia, gathers estates by purchase and exchange from Grigoraș Sturza treasurer, from the ban Ioan Vîrnav and from Dimitrie Bogdan (with the last one he made the deal for Lei 292,000), was published by Georgescu-Vrancea (1934, p. 175-180).

${ }^{9}$ For the original document, see ANI, 320/79; see also the two documents of December 1813, which clarify certain details of the transaction (Lapedatu, 1916, p. 27-29, issues 9-10).

${ }^{10}$ BAR, Doc. ist., CXIV/151 (of February $6^{\text {th }}, 1814$, prince Scarlat Calimachi ordered a "line of guards, from Siret to the mountain, up to Vrancea, to protect against the plague").

${ }^{11}$ A generation before, without the villages of the Hotin raya, Moldova, the regions on the left bank of the Pruth counted around 500 villages, according to the Russian censuses of 1772-1773 and 1774 and to the "register of taxpayers" of 1803 (Dmitriev, 1973, p. 46-47, 64). 
possessions not be separated, the villages owned by the boyars who settled in Bessarabia, the villages of free villagers and the villages of monasteries. The information-comprised in this synthetic document-also mentions the owners of the villages and parts of villages in 1812, even though in some cases the owner may have changed between the moment of the occupation and the moment of sale or exchange, mostly due to the shift of ownership rights between the branches of the same family. And, at the same time, the document fails to mention the prices paid for these villages, on one hand because the parties did not quite wish to reveal them, on the other because many of the reported amounts had hidden stories behind them.

Without any other story than the tragic death of the Moruzi brothers (Iorga, 1910; Goșu, 1998), I mention the exchange of November $16^{\text {th }}, 1813$, through which the comis Ioan Bals took from Constantin Alexandru Moruzi and from the heirs "of princes Dimitrie and Panaitache", represented by the following vestrymen: Costache Ghica chancellor, Sandul Sturza hetman and Răducanu Roset hetman, the entire estate, Hotărniceni ${ }^{12}$, and the nearby estate, Molești (see also the registry below), giving them in exchange the following estates: Pașcani, in the region of Suceava, Ezăreni and Giulești, called Hodora, in the region of Hîrlău, and Conțești, bordered by the estate of Pașcani (this estate was "purchased definitively", for Lei 250 annually, from the monastery of Probota), along with the amount of Lei 40,000. The exchange was done, comis Balș states, with the consent of the ecumenical patriarch and pursuant to the "high command of separating, for the satisfaction of the creditors who will take from the house of the late princes Dimitrie and Panaitache, precisely pursuant to the holy treaties and to the confirmation of the higher orders, wishing to separate one side and the other from the estates of foreign domination" (ANI, Doc., 340/48) ${ }^{13}$. The exchange really occurred, because on July $22^{\text {th }}, 1814$, the vestrymen auctioned, with the prince's consent, the estates on the right bank of the Pruth (ANI, Doc., 143/75).

A true story is represented by the extraordinary-literally and figuratively-sales of estates, which occurred in a single day, on December $21^{\text {th }}, 1813$, the protagonist being the comis Alexandru Panaite. Among the documents drafted up at that point, following a similar form of chancellery, I discovered five, but there may be more, of course. The higher motivation of the sales and purchase action is expressed clearly: "pursuant to the orders issued by the administration, empowered by the power of the treaties for all those with estates and annexes, namely to the left bank of the Pruth, those residing on the right of the Pruth, and to the right of the Pruth, those residing on the left bank of the Pruth, to be able to separate the assets until deadline, January $2^{\text {th }}, 1814$, using whatever means necessary to obey this order". And the immediate and main reason for which sellers had serious trouble finding buyers is similarly formulated: "they could by no means find good exchange deals, either to give or to receive, on the right side of the Pruth".

Hence, knowing the buyer, I present the sellers, the villages and the amounts: Iordache Roset forner great treasurer, sells the small town of Briceni and the estates of Hrubna and Hrimancăuți, with common border, with the region of Hotin, as well as the small town of Soroca and the estate of Rublenița, with common border, with the region of Soroca, for Lei 550,000 (ANI, Doc., 341/11 and 341/5) ${ }^{14}$; Neculai Roset former great spatharus sells the estates: Rădești, Șcheia, half of Mălești, half of Tăisăni, three parts of Trielești, "with common border, known as Sculeni", with the region of Iași, alongside "the quarantine from the left of the Pruth", for Lei 400,000 (ANI, Doc., 341/10 and 341/4); the female spatharus Catinca Ghica sells the estates: Medvica or the small town of Lipcani, Crușăuți, Cîşla Zamgiului, Răsteul, Hlinaia and Coșuleni, with common border, with the region of Hotin, half of Șofricani and half of Pașuțeni, with common border, with the region of Iași, Zăhăicani, Stolniceni, Stîngăceni and half of Hiliuți, with common border, with the region of Iași, the small town of Rezina and the estate of Tohnoaia, with common border,

\footnotetext{
${ }^{12}$ The estate of Hotărniceni was embedded in Moldavia in 1775 by Grigore Alexandru Ghica, who gifted it to his sons Dimitrie and Alexandru (Năstase, 1933, p. 318-322).

${ }^{13}$ The comis Ioan Balș also sold his estate on the right bank of the Pruth, which also comprised 74 Gypsy settlements (371 people). They were sold on December $18^{\text {th }}, 1813$, to magistrate Dimitrie Bogdan, for Lei 42,665 (ANI, Doc., 606/34).

${ }^{14}$ Originals, one featuring the buyer's signature and the other, the seller's signature; the three subsequent sales and purchase agreements are also doubles.
} 
with the region of Orhei, Sărăteni, Avrămeni, Coromîslești, parts of Coropceni, parts of Hîjdăeni, parts of Ciocilteni, with common border, the region of Orhei, Perieni, Măzărești, half of Roșcani, with common border, with the region of Orhei, for Lei 909,000 (ANI, Doc., 341/9 and 341/7); the female treasurer Anica Bogdan, wife of treasurer Iordache Roset, sells the estate of Sărata, in the region of Iași, for Lei 80,000 (ANI, Doc., 341/8 and 341/6). The total price, Lei 1,939,000! The hidden parts of these contracts come to light partially upon reading the clause featured in all of them, briefly or more elaborately. There it is, as shown in the sales agreement of the female spatharus Catinca Ghica ${ }^{15}$ : "they will pay me in instalments, for twelve years, without any interest, and all the income from the estates will be given to me as interest for the money, minus the annual maintenance expenses for the estates". Because the aforementioned sellers were blood relatives, comis Alexandru Panaite issued in the same day a document where he acknowledges that he is only "the administrator and caretaker" of these estates, without showing that he would want to buy them someday (ANI, Doc., 143/74). This stands to show that the 12 years mentioned in the contracts proved to be only a cover-up and an "economy-based change", until "the country will be under an occupation or will change the occupation" (Lapedatu, 1916, p. 12, 23-24, issue 6) ${ }^{16}$. Moreover, it appears that these documents were not long standing ${ }^{17}$, partly because they are not mentioned in the list below and partly because, as early as the spring of 1814 , some of the estates were claimed by the sellers again.

Another lucky buyer was the bread supplier Teodosie, who only a few days before the "18-month deadline", bought on December $30^{\text {th }}$ and $31^{\text {st }}, 1813$ from Nastasia Roset-daughter of the late Neculai Roset chancellor and wife of the ban Costachi Razu, her dowry estates: Pripiceni, with the village of Dubna, half of Părcanile, half of Ciripcău, in the region of Soroca, for which the seller got the approval of her brother, Iordache Roset treasurer, for Lei 60,000 (ANI, Doc., 215/8), and from Safta Costachi, daughter of magistrate Costandin Costachi and wife of the comis Teodor Sturza, the estates: Cunice, with annexes and with village, and a part of Hăsnăşăni, with a pond and stone mill on Cobolta, also in the region of Soroca, for Lei 80,000 (ANI, Doc., 462/50; Ghibănescu, 1914, p. 353-356). Previously, on December $1^{\text {st }}$, he bought from the vestrymen of the sultan prince Costachi Moruzi and from princess Ralu, the daughter of Alexandru Costandin Mavrocordat, the small town of Telinești, in the region of Orhei, for Lei 90,000 (ANI, Doc., 191/61 ${ }^{18}$; Costăchescu, 1930, p. 35). These sales really occurred and they are enumerated in the list below, and Teodosie the pitar took these estates into possession and through the will made on November $13^{\text {th }}, 1817$, he left them to his children (Costăchescu, 1930, p. 145-147) ${ }^{19}$.

During the same days, the owners of estates from the left of the Pruth, who chose to live on the right side of the river, looked for ad-hoc solutions to solve the situation. One of these solutions, used on a large scale, is revealed by a document dated February 15, 1816, through which Teodor Bals former great magistrate, changes estates with Ioan Străzescu and his wife, Maria; the magistrate gives three parts of the estate of Trebujăni, on Ciuhur, in the regions of Hotin and Iași, "where the village of Horodiște is located", and he takes the fourth part of the estate of Ciurești and parts of the estates of Chilieni and Păcurărești, in the region of Tutova, which were the dowry of Maria, as well as Lei 12,000. But until that moment, Teodor Balş shows the following: "As a subject of the Ottoman Porte, pursuant to the holy treaties, I started separating estates and parts of estates, which I had received from my parents and from other relatives and which were located in the region of Hotin, shown in the auction documents, and I

\footnotetext{
${ }^{15}$ Catinca Ghica was the wife of Nicolae Roseti-Roznovanu (ANI, Doc., 341/13), from whom she divorced following an infamous suit; see also Rosetti, 1938, p. 121-122).

${ }^{16}$ On December $28^{\text {th }}, 1813$, Manolache Radu former great serdar gave to Enăcachi the treasury employee the estate of Lucăceni on the left of the Pruth, in exchange for the estate of Lucești, in the region of Tutova, parts of Buhăești and Comănești, in the region of Vaslui, and 5 acres of vineyard in Odobești, hoping that the treasury employee, being a merchant, will find a way to make profit from the estate in Bessarabia (ANI, Doc., 413/54), but on January $1^{\text {st }}$, the parties made a new document, through which they show that they keep the documents of the estates, in order to annul the exchange, upon request (ANI, Doc., 413/62).

${ }^{17}$ These estates are not listed among the possessions of the comis Alexandru Panaite (Bezviconi, 1943, p. 57).

${ }^{18}$ The document pertains to the archive of the Bessarabian historian Paul Gore, given to the National Archives in Iași.

${ }^{19}$ For the pitar Teodosie (Teodosiu), see also Bezviconi (1940, p. 145-147).
} 
auctioned them; because the auction was published and nobody rose any claims, I managed to sell them to the subject of the Russian Empire, namely the comis Iancu Bals, as shown in the auction documents drafted up on December $28^{\text {th }}$, 1813. The comis did not have money to pay upfront, we have agreed upon instalment-based payments, with interest, on a four-year basis". However, because for two years the comis made no payment, "I was forced to come in person here, in Kishinev, where in order to avoid any legal action I bought the estates and parts of estates and I became the owner" (ANI, Doc., 210/1).

\section{Conclusions}

Besides the apparent or "shady" sales, mentioned above, several others are featured in the document I publish as follows, because some of the "sold" estates are featured in the 1817 land catagraphy of the localities in Bessarabia, owned by the residents of Moldavia on the right bank of the Pruth (Halippa, $1907)^{20}$. Nonetheless, taking into account that in this catagraphy the number of owners residing in Moldavia is very large, while the number of sales and purchase agreements and estate exchange in Bessarabia, starting with January 1814, is very small, this census may have recorded the owners before the sales and exchange wave in November-December 1813. After the beginning of the year 1814, the trepidation of "real estate fair" calmed down, and the process of noble estate "separation" for the estates situated on one side and the other of the Pruth only produces, over several years, only a few property seeking documents ${ }^{21}$, sales rearrangement documents ${ }^{22}$, compensation for the princely boyars in Moldavia for the lost estates in Bessarabia $^{23}$ or for apparent leasing of estates ${ }^{24}$.

All things considered, it may be concluded at a general level from the documents featured above and from the list below, that the separation of estates and families led to a breaking of the country but at the same time, secondarily, this multitude of names of settlements and masters may be used, sometimes in the future, to the elaboration of a historical and toponymic study of the localities from the left of the Pruth $^{25}$, following the model of the one elaborated for the localities on the right bank of the Pruth by the toponymy collective with the "A. Philippide" Romanian Philology Institute, coordinated by Professor Dragoș Moldovanu.

\section{Bibliography}

\section{A. Sources}

ADIRR $=$ Acte și documente relative la istoria renaşterii României, publicate de Ghenadie Petrescu, Dimitrie A. Sturdza și Dimitrie C. Sturdza, vol. I, București.

${ }^{20}$ This census was published fragmentarily and published by: Tomescu (1927), Porucic (1933), Teodorescu (1935, 1936, 1937, 1938), Mutruc (2003).

${ }^{21}$ The same owner Catinca Ghica, after divorcing Neculai Roset, sought on May $9^{\text {th }}, 1817$, to take possession of her dowry estates, on the left and the right side of the Pruth, from the vestrymen Dimitrie Sturza chancellor and Răducanu Roset hetman (ANI, Doc., 479/25 and 143/83).

${ }^{22}$ On May $15^{\text {th }}, 1817$, Costandin Sturza former great aga sells to Gheorghe Potirachi major the estates of Vlădești and Brițcani, in the region of Greceni, "inheritance from his parents", left after dividing them with his brother, Ștefan Sturza spatharus, for Lei 110,000, through the administrator "Ioan Sturza former high spatharus, a subject of the Russian empire" (ANI, Doc., 611/5).

${ }^{23}$ On September $10^{\text {th }}, 1814$, the treasurer wife Zmaragada Balș, who receives from Scarlat vodă Calimachi 50 tax-exempted employees, because due to "the new border of Pruth, most of her estate, Zberoaia, in the region of Iaşi, which was her dowry, remained on the left side of the Pruth, while the people working for her, the village, the house and others remained on that side altogether" (ANI, Doc., 462/59).

${ }^{24}$ In June 1826, hetman Iordachi Balş and his wife Anica Balș leased to the cupbearer Mihalache Chinezu, the income of their estates in the region of Iași, "in the region of Bessarabia": Dănuțăni, with the villages of Oișeni, Băilești, Țuțora Nouă and Țuţora Veche, Vladnicul, with its villages, and Pîrliții, for four years, for Lei 3,000 per year; but who can tell how the lessee honoured his contract obligations given that he lived in Iași! (ANI, Doc., 229/2).

${ }^{25}$ As far as I now, the dictionary drafted up by Vladimir Nicu remained the only attempt of such type after the fall of communism Nicu (1991). 
ANB, Doc. mold. $=$ Arhivele Naţionale București, Documente moldovenești.

ANI, Doc. $=$ Arhivele Naționale Iași, Documente.

BAR, Doc. ist. = Biblioteca Academiei Române, București, Documente istorice.

Bezviconi, Gh. (1940). Boierimea Moldovei dintre Prut și Nistru, Actele Comisiei pentru cercetarea documentelor nobilimii din Basarabia, la 1821, publicate de Gheorghe G. Bezviconi, vol. I, București.

Bezviconi, Gh. (1943). Boierimea Moldovei dintre Prut și Nistru. Actele Comisiei pentru cercetarea documentelor nobilimii din Basarabia, la 1821, publicate de Gheorghe G. Bezviconi, vol. II, București.

Doc. Mold. $=$ Documente privind istoria Moldovei sub ocupația militară rusă (1806-1812), vol. întocmit de A. Agachi, I. Varta, V. Constantinov, L. Svetlicinâi, T. Varta, Chișinău, 2012.

Doc. T. Mold. = Documente privitoare la istoria Țării Moldovei in perioada războiului ruso-turc (august 1808 - iunie 1809), vol. întocmit de Demir Dragnev, Larisa Svetlicinâi, Teodor Candu, Tudor Ciobanu, București-Brăila, 2017.

Drăghici, M. (2017). Istoria Moldovei pe timp de 500 de ani pînă in zilele noastre. Ediție, introducere și note de Andrei Pippidi, Editura Academiei Române, București.

Ghibănescu, Gh. (1914). Surete și izvoade, vol. IX (Documente basarabene), ed. Gh. Ghibănescu, Iași.

Halipра, I. (1907). Роспись землвладпнізя и сословнаго строя населенія Бессарабіи по данньммб переписи 1817 года, în „Труды Бессарабской Губернской Ученой Архивной Комиссии", III, Chișinău, p. 3-229.

Sava, A.V. (1933). Crîmpeie din viaţa Basarabiei sub ruşi (1812-1830), II, nr. 11, p. 677-692.

Sava, A.V. (1935a). Din istoria problemei agrare in Basarabia. Răzvrătire țărănească în tîrgul Lăpușnei. Raporturile dintre săteni și proprietarul moșiei după răpirea Basarabiei. Înrăutățirea regimului sub ruși. Lista gospodarilor din Lăpușna in 1817, în „Arhivele Basarabiei”, VII, nr. 2, p. 145-160.

Sava, A.V. (1935b). Din istoria problemei agrare în Basarabia. Răzvrătire țărănească în tîrgul Lăpuşnei, în „Arhivele Basarabiei”, VII, nr. 3-4, p. 241-256.

Tomescu C.N. (1927). Catagrafia Basarabiei din 1817. 1. Ținutul Hotinului, Chișinău, 1927, p. 3-49.

\section{B. References}

Bezviconi, Gh. (1936). Din vremea lui Alexandru Sturdza (1791-1854), in “Din trecutul nostru”, iss. 36-39, p. 1-81.

Casso, L. (1940). Rusia și basinul dunărean, transl. by Șt. Gr. Berechet, Iași.

Cazacu, P. (1992). Moldova dintre Prut și Nistru (1812-1918), Chișinău.

Costăchescu, M. (1930). Satul și tîrgul Telinești din județul Orhei. Schiță istorică, Iași.

Dmitriev, P. G. (1973). Народнонаселение Молдавии (по материалам переписей 1772-1773, 1774 и 1803 г2.), Chișinău.

Goșu, A. (1998). Pacea de la București și Moruzeștii, in Național și universal in istoria românilor. Studii oferite prof. dr. Şerban Papacostea cu ocazia implinirii a 70 de ani, edited by Ovidiu Cristea and Gheorghe Lazăr, București, p. 362-387.

Goșu, A. (2008). Între Napoleon și Alexandru I. Principatele dunărene la începutul secolului al XIX-lea, București.

Georgescu-Vrancea, C. (1934). Boierimea basarabeană și pacea din București din anul 1812, in “Arhivele Basarabiei”, VI, iss. 2, p. $175-180$.

Gumenâi, I. (2002). Istoria ținutului Hotin de la origini pînă la 1806, Chișinău.

Iorga, N. (1910). Alte lărmuriri despre veacul al XVIII-lea după izvoare apusene. Luarea Basarabiei și Moruzeștii, București.

Iorga, N (1912a). Din ținuturile pierdute. Boieri și răzeși în Bucovina și Basarabia în cele dintîi decenii după anexare, București.

Iorga N. (1912b). Basarabia noastră. Scrisă după 100 de ani de la răpirea ei de către ruși (Studii și documente cu privire la istoria românilor, vol. XXIV), Vălenii de Munte.

Iorga, N. (1938). Istoria românilor, vol. VIII (Revoluționarii), București.

Iorga, N. (1995). Neamul românesc în Basarabia. Ediție îngrijită, introducere, note și bibliografie de Iordan Datcu, Ed. Fundației Culturale Române, București.

Lapedatu, Al. (1916). Documente și lămuriri istorice cu privire la desfacerea proprietăților moldovene de peste Prut dupăpierderea Basarabiei (16/28 mai 1812 - 2/14 ianuarie 1814), București.

Mutruc, V., (2003). Cu privire la evoluţia proprietății funciare în Basarabia în prima jumătate a secolului al XIX-lea, în In memoriam professoris Mihail Muntean, editors: Valentin Tomuleț, Igor Șarov, Igor Ojog, Aurel Zanoci, Chișinău, p. 114136.

Năstase, Gh.I. (1933), „Hotarul lui Halil Pașa” și „cele 2 Ceasuri”. Schițarea unei probleme de geografie istorică și politică moldovenească, in "Viața Basarabiei", II, iss. 6, p. 309-322.

Nicu, V. (1991). Localitățile Moldovei in documente și cărți vechi. Îndreptar bibliografic, vol. I-II, Chișinău.

Nistor, I. (1991). Istoria Basarabiei, Chişinău.

Niță-Danielescu, D. (2017). Mănăstirile „inchinate” din Moldova în anii războiului ruso-turc (1806-1812), în Relațiile românilor cu Muntele Athos și cu alte Locuri Sfinte (sec. XIV-XX). In honorem Florin Marinescu, editor Petronel Zahariuc, Editura Universității „Alexandru Ioan Cuza”, Iaşi, 2017, p. 385-393.

Porucic, T. (1933). Regiunile naturale dintre Prut și Nistru, in "Viața Basarabiei", year II, iss. 3, p. 156-167.

Poștarencu, D. (2006). Anexarea Basarabiei la Imperiul Rus, Chișinău.

Rosetti, R. (1909). Arbiva Senatorilor din Chişinău și ocupaţia rusească de la 1806 la 1812, III (Amänunte asupra Moldovei de la 1808 la 1812), București. 
Rosetti, R. (1938). Familia Rosetti, I (Coborîtorii moldoveni ai lui Lascaris Rousaitos), București.

Sturdza, M.D. (2004). Familiile boierești din Moldova și Țara Românească. Enciclopedie istorică, genealogică și biografică, vol. I, coordonator și coautor Mihai Dim. Sturdza, București.

Teodorescu, C. (1935). Moldova și Basarabia 1807-1817, in “Arhivele Basarabiei”, VII, iss. 1, p. 45-73.

Teodorescu, C. (1936). Moldova și Basarabia în 1807-1817. Averea mișcătoare și poporația jud. Hotin, in "Arhivele Basarabiei”, VIII, iss. 4, p. 266-275.

Teodorescu, C. (1937). Moldova și Basarabia 1807-1817. Averea nemișcătoareșipoporația județului Soroca în 1817, in "Arhivele Basarabiei", IX, iss. 1-4, p. 102-111;

Teodorescu, C. (1938). Moldova și Basarabia 1807-1817. Averea nemişcătoare și poporația județului Soroca, in "Arhivele Basarabiei”, X, iss. 1-4, p. 129-138.

Tomuleț, V. (2007). Cronica protestelor și revendicărilor populației din Barabia (anii 1812-1828), Chișinău, 2007.

Tomuleț, V. (2014). Basarabia în epoca modernă (1812-1918). Instituții, regulamente, termeni, ediția a II-a, revăzută şi adăugită, Chișinău.

\section{Appendix A. ANB, Doc. mold., XIII/12. Original, paper, 6 pages.}

Document of the estates bought in the region of Bessarabia, comprising the names of villages and of their regions, and the names of buyers and sellers. February 1814

\begin{tabular}{|c|c|c|c|c|}
\hline No. & Name of estate & & Who sold & Who bought \\
\hline 1 & Tudorenii & \multirow{4}{*}{ in the region of Greceni } & \multirow{4}{*}{ spatharus Iordachi Roset } & \multirow{4}{*}{ comis Iancul Balș } \\
\hline 2 & Petreceuca & & & \\
\hline 3 & Besăreca & & & \\
\hline 4 & Corcanii & & & \\
\hline 5 & Cimișăni & \multirow{4}{*}{ in the region of Orhei } & \multirow{4}{*}{$\begin{array}{l}\text { administrator } \\
\text { chamberlain Costachi } \\
\text { Haret }\end{array}$} & \multirow{4}{*}{ comis Costachi Sturza } \\
\hline 6 & Roșcanii & & & \\
\hline 7 & $\begin{array}{l}\text { parts of Cobusca de Sus } \\
\text { and de Gios in Orhei }\end{array}$ & & & \\
\hline 8 & Petricanii in Orheiu & & & \\
\hline 9 & $\begin{array}{l}\text { Vornicenii in the region } \\
\text { of Hotin }\end{array}$ & \multirow{4}{*}{ in the region of Soroca } & \multirow{10}{*}{$\begin{array}{l}\text { magistrate Dimitrachi } \\
\text { Bogdan }\end{array}$} & \multirow{10}{*}{ spatharus Ioniță Bașotă } \\
\hline 10 & Ghizdita & & & \\
\hline 11 & Vale Țarigradului & & & \\
\hline 12 & Pustiul & & & \\
\hline 13 & $\begin{array}{l}\text { Micoreni with the } \\
\text { villages }\end{array}$ & \multirow[t]{3}{*}{ in the region of Orhei } & & \\
\hline 14 & $\begin{array}{l}\text { Țahnăuții with the } \\
\text { villages }\end{array}$ & & & \\
\hline 15 & Holboca & & & \\
\hline 16 & $\begin{array}{l}\text { Șoltoae with the villages, } \\
\text { in the region of Iași }\end{array}$ & & & \\
\hline 17 & Tîrteștii & \multirow{2}{*}{ in the region of Greceni } & & \\
\hline 18 & Coplenii & & & \\
\hline 19 & $\begin{array}{l}\text { from the estate of } \\
\text { Ialovăt, } 2 \text { parts, in the } \\
\text { region of Orhei }\end{array}$ & & ban Ion Vârnav & spatharus Ioniță Bașotă \\
\hline 20 & Popornița & \multirow{6}{*}{ in the region of Iași } & \multirow{6}{*}{ treasurer Grigoraș Sturza } & \multirow{6}{*}{ spatharus Ioniță Başotă } \\
\hline 21 & $\begin{array}{l}\text { Nicorenii, also called } \\
\text { Ochi Albu }\end{array}$ & & & \\
\hline 22 & $\begin{array}{l}\text { Corcotenii with the } \\
\text { villages }\end{array}$ & & & \\
\hline 23 & Răciula, with the villages & & & \\
\hline 24 & Aluniș, without village & & & \\
\hline 25 & Dondăşănii, with village & & & \\
\hline 26 & $\begin{array}{l}\text { Mărceștii in the region } \\
\text { of Orhei }\end{array}$ & & the Metropolis of Iaşi & spatharus Ioniță Başotă \\
\hline
\end{tabular}




\begin{tabular}{|c|c|c|c|c|}
\hline 27 & $\begin{array}{l}\text { Corneștii, also called } \\
\text { Cotelna, with the parts, } \\
\text { in the region of Lăpușna }\end{array}$ & & magistrate Dimitrii Ralet & $\begin{array}{l}\text { collector of duties on } \\
\text { spirits Zamfirachi Rale }\end{array}$ \\
\hline 28 & Căpreștii & \multirow{2}{*}{ in the region of Soroca } & \multirow{2}{*}{$\begin{array}{l}\text { spatharus Alexandru } \\
\text { Mavrocordat }\end{array}$} & \multirow{2}{*}{$\begin{array}{l}\text { Costandin Iofce great } \\
\text { captain }\end{array}$} \\
\hline 29 & Porcarii & & & \\
\hline 30 & Dărcăuții & \multirow{3}{*}{$\begin{array}{l}\text { same, in the region of } \\
\text { Soroca }\end{array}$} & \multirow{3}{*}{ the Metropolis of Iași } & \multirow{3}{*}{$\begin{array}{l}\text { sardar Alexandru } \\
\text { Anastasiu }\end{array}$} \\
\hline 31 & Heleceu & & & \\
\hline 32 & Braicăul & & & \\
\hline 33 & Costuleni & \multirow{3}{*}{ in the region of Iaşi } & \multirow{3}{*}{$\begin{array}{l}\text { same, of the Metropolis } \\
\text { din Iași }\end{array}$} & \multirow{3}{*}{$\begin{array}{l}\text { still sardar Alexandru } \\
\text { Anastasiu }\end{array}$} \\
\hline 34 & Prisăcani & & & \\
\hline 35 & Hăuleștii & & & \\
\hline 36 & $\begin{array}{l}\text { Morțăștii with the } \\
\text { villages, in the region of } \\
\text { Lăpușnii }\end{array}$ & & $\begin{array}{l}\text { spatharus's wife Safta } \\
\text { Bogda }\end{array}$ & $\begin{array}{l}\text { chamberlain's wife } \\
\text { Ghedeonovei }\end{array}$ \\
\hline 37 & Văsienii & \multirow{7}{*}{ in the region of Orhei } & \multirow{7}{*}{ spatharus Iancul Milcescu } & \multirow{7}{*}{ spatharus Ioniță Başotă } \\
\hline 38 & Manoileștii & & & \\
\hline 39 & Policenii & & & \\
\hline 40 & Comăneștii & & & \\
\hline 41 & Vișnăei ${ }^{26}$ & & & \\
\hline 42 & Bețănii & & & \\
\hline 43 & Mînzatu & & & \\
\hline 44 & $\begin{array}{l}\text { Volniceni, also called } \\
\text { Potani, in the region of } \\
\text { Hotin }\end{array}$ & & $\begin{array}{l}\text { șatrar's wife Ralița } \\
\text { Bosiiasa }\end{array}$ & school registrar Ianov \\
\hline 45 & $\begin{array}{l}\text { the fourth part of the } \\
\text { estate of Iurcenii, in the } \\
\text { region of Orhei }\end{array}$ & & & \\
\hline 46 & $\begin{array}{l}\text { Hulpeștii, in the region } \\
\text { of Iaşi }\end{array}$ & & $\begin{array}{l}\text { cupbearer's wife } \\
\text { Paraschiva Iurașcova }^{27}\end{array}$ & her son Costandin \\
\hline 47 & $\begin{array}{l}\text { Hotărniceni, with all the } \\
\text { villages }\end{array}$ & & \multirow[t]{2}{*}{ the vestrymen D. Moruz } & \multirow[t]{2}{*}{ comis Iancul Balș } \\
\hline 48 & Moleștii & & & \\
\hline 49 & $\begin{array}{l}\text { Drojdieștii, in the region } \\
\text { of Soroca }^{28}\end{array}$ & & aga Alecu Cantacuzino & Luca Estratiul \\
\hline 50 & $\begin{array}{l}\text { Ochinceștii, in the } \\
\text { region of Soroca }\end{array}$ & & $\begin{array}{l}\text { Rocsanda Roset } \\
\text { spatharus's wife }\end{array}$ & $\begin{array}{l}\text { Chamberlain Iordachi } \\
\text { Frunzăti }\end{array}$ \\
\hline 51 & $\begin{array}{l}\text { Șărbăneștu }{ }^{29}, \text { the } 16^{\text {th }} \\
\text { part of the } 4^{\text {th }} \text { part }\end{array}$ & & $\begin{array}{l}\text { priest Pantelimon } \\
\text { Petrachi }\end{array}$ & $\begin{array}{l}\text { the inhabitants of } \\
\text { Bukovina; Iordachi Tăut }\end{array}$ \\
\hline 52 & $\begin{array}{l}\text { Fădcăuții with a } 3^{\text {rd }} \text { of } \\
\text { three original estates } \\
\text { (bătrini). These parts are } \\
\text { both in the region of } \\
\text { Hotin }\end{array}$ & & & and Gheorghii Savinschii \\
\hline 53 & $\begin{array}{l}\text { from Forosca the } 32^{\text {nd }} \\
\text { part }\end{array}$ & \multirow[t]{3}{*}{ in the region of Hotin } & \multirow{3}{*}{$\begin{array}{l}\text { Gheorghii Alexandri and } \\
\text { Dumitru Luțchii }\end{array}$} & \multirow[t]{3}{*}{ all mentioned above } \\
\hline 54 & Șărbănețul & & & \\
\hline 55 & $\begin{array}{l}\text { from Fătcăuți the } 18^{\text {th }} \\
\text { part }\end{array}$ & & & \\
\hline 56 & $\begin{array}{l}\text { Modvaliche }{ }^{30} \text {, in the } \\
\text { region of Orhei }\end{array}$ & & $\begin{array}{l}\text { the treasury employee's } \\
\text { wife Catrina Cozmuliasa }\end{array}$ & caminar Zamfirache Rale \\
\hline
\end{tabular}

\footnotetext{
${ }^{26}$ Probably: „Văsieni”.

${ }^{27}$ Uncertain reading.

${ }^{28}$ First the author wrote: "Orheiului", then he corrected it.

${ }^{29}$ Original version; probably: „Șerbinți”.

${ }^{30}$ Original version; I did not find the names of villages in the village lists of the Orhei region.
} 


\begin{tabular}{|c|c|c|c|c|}
\hline 57 & $\begin{array}{l}\text { the fourth part of } \\
\text { Hrușevăț, in the region } \\
\text { of Hotin }\end{array}$ & & $\begin{array}{l}\text { the colonel's wife Soltana } \\
\text { Tălpoai }\end{array}$ & Dumitru Sălcian \\
\hline 58 & Brătulenii & \multirow{7}{*}{ in the region of Iaşi } & \multirow{7}{*}{$\begin{array}{l}\text { pitar Vasili Coroiu, with } \\
\text { his sister, Iliana, given } \\
\text { pursuant to the will }\end{array}$} & \multirow{7}{*}{$\begin{array}{l}\text { the sons of Vasili: } \\
\text { Gheorghii and the girls, } \\
\text { Zmăranda and Profira }\end{array}$} \\
\hline 59 & Morăștii & & & \\
\hline 60 & Negreștii & & & \\
\hline 61 & Horăștii & & & \\
\hline 62 & Marcăru $^{31}$ & & & \\
\hline 63 & Corneștii & & & \\
\hline 64 & Hotineștii & & & \\
\hline 65 & the $6^{\text {th }}$ part of Hădărăuți & \multirow{2}{*}{ in the region of Hotin } & \multirow{2}{*}{$\begin{array}{l}\text { high steward Grigori To- } \\
\text { mița and Costache Manole }\end{array}$} & \multirow{2}{*}{ sardar Manolachi Radul } \\
\hline 66 & half of Măndăcăuți & & & \\
\hline 67 & Miclăușăni & \multirow{2}{*}{ in the region of Iași } & \multirow{2}{*}{ Ion Scorțăscu } & \multirow{2}{*}{ command captain Stroici } \\
\hline 68 & half of Trilești & & & \\
\hline 69 & $\begin{array}{l}\text { the fourth part of } \\
\text { Ținești, the region of } \\
\text { Hotin }\end{array}$ & & Vasili Lână & lui Iordachi Morțun \\
\hline 70 & $\begin{array}{l}\text { the third of Dumeni, the } \\
\text { region of Hotin }\end{array}$ & & $\begin{array}{l}\text { cupbearer's wife Nastasie } \\
\text { Stamate }\end{array}$ & cupbearer Toma Stamate \\
\hline 71 & $\begin{array}{l}\text { Meșănii, in the region of } \\
\text { Orhei }\end{array}$ & & major Dănca & still Stamate \\
\hline 72 & $\begin{array}{l}\text { Stăuceni, the region of } \\
\text { Hotin }\end{array}$ & & ban Ioniță Prăjăscu & still Stamate \\
\hline 73 & Criveștii & \multirow{17}{*}{ in the region of Soroca } & \multirow{17}{*}{$\begin{array}{l}\text { spatharus Alexandru } \\
\text { Ghica }\end{array}$} & \multirow{17}{*}{$\begin{array}{l}\text { chamberlain Alexandru } \\
\text { Ghica }\end{array}$} \\
\hline 74 & Horghineștii & & & \\
\hline 75 & Cărăpușăni & & & \\
\hline 76 & Pepelenii & & & \\
\hline 77 & Visternicenii & & & \\
\hline 78 & Cotuleștii & & & \\
\hline 79 & Pogribeni & & & \\
\hline 80 & Băgrăneștii & & & \\
\hline 81 & Mărculeștii & & & \\
\hline 82 & Trepeteni & & & \\
\hline 83 & Floreștii & & & \\
\hline 84 & Buneștii & & & \\
\hline 85 & Săvirova & & & \\
\hline 86 & Albeștii & & & \\
\hline 87 & Coșărnița & & & \\
\hline 88 & Ciornița & & & \\
\hline 89 & Solonețul & & & \\
\hline 90 & $\begin{array}{l}\text { Ghincesstii, in the region } \\
\text { of Soroca }\end{array}$ & & sardar Isac Fedor & $\begin{array}{l}\text { high steward Matei } \\
\text { Râșcanu }\end{array}$ \\
\hline 91 & $\begin{array}{l}\text { Fundurelile, in the } \\
\text { region of Iași }\end{array}$ & & $\begin{array}{l}\text { cupbearer Costandin } \\
\text { Miclescu }\end{array}$ & cupbearer Toma Stamate \\
\hline 92 & $\begin{array}{l}\text { Țipirica, in the region of } \\
\text { Orhei }\end{array}$ & & $\begin{array}{l}\text { spatharus Dumitrachi } \\
\text { Jora }\end{array}$ & same, to Stamate \\
\hline 93 & Vlădeștii & \multirow{3}{*}{ in the region of Grecenii } & \multirow{3}{*}{$\begin{array}{l}\text { spatharus Costandin } \\
\text { Sturza }\end{array}$} & \multirow{3}{*}{ spatharus Ioan Sturza } \\
\hline 94 & Brețcanii & & & \\
\hline 95 & $\begin{array}{l}\text { half of Rujăneț, called } \\
\text { Bîrlădeni }\end{array}$ & & & \\
\hline 96 & Budeștii & \multirow{5}{*}{ in the region of Orhei } & \multirow{5}{*}{ treasurer Grigoraș Sturza } & \multirow{5}{*}{$\begin{array}{l}\text { collector of duties on } \\
\text { spirits Panaite Cazimir }\end{array}$} \\
\hline 97 & Dumăneștii & & & \\
\hline 98 & Chițcanii & & & \\
\hline 99 & Negurenii & & & \\
\hline 100 & a part of Pupăzăni & & & \\
\hline
\end{tabular}

\footnotetext{
${ }^{31}$ Original version; maybe a wrong spelling for: "Măcărești” (?).
} 


\begin{tabular}{|c|c|c|c|c|}
\hline 101 & $\begin{array}{l}\text { Tîrșițăni, in the region } \\
\text { of Soroca }\end{array}$ & & & \\
\hline 102 & $\begin{array}{l}\text { Borzăștii, with other } \\
\text { parts, in the region of } \\
\text { Iași }\end{array}$ & & & \\
\hline 103 & 244 meters in Moruzăni & \multirow{2}{*}{ the region of Orhei } & \multirow{2}{*}{$\begin{array}{l}\text { the vestrymen Catrini } \\
\text { Stăvilă }\end{array}$} & \multirow[b]{2}{*}{ same, to Cazimir } \\
\hline 104 & half of Crucești & & & \\
\hline 105 & Costurenii $^{32}$ & \multirow{5}{*}{ within the region of Iași } & \multirow{5}{*}{$\begin{array}{l}\text { the vestrymen of Toader } \\
\text { Carp: collector of duties } \\
\text { on spirits Ioan Carp and } \\
\text { captain Dumitru Carp }\end{array}$} & \multirow{5}{*}{$\begin{array}{l}\text { cupbearer Toma Stamate } \\
\text { and medelnicer Andrieș }\end{array}$} \\
\hline 106 & of Bălășăști, parts & & & \\
\hline 107 & of Bîncicani, parts & & & \\
\hline 108 & of Milești & & & \\
\hline 109 & of Cobăești & & & \\
\hline 110 & $\begin{array}{l}\text { half of the estate of } \\
\text { Cărpițta, in the region of } \\
\text { Iași }\end{array}$ & & $\begin{array}{l}\text { collector of duties on } \\
\text { spirits Ioan Carp }\end{array}$ & $\begin{array}{l}\text { medelnicer Mandachi } \\
\text { Andrieș }\end{array}$ \\
\hline 111 & Fedeștii & \multirow{2}{*}{ the region of Iași } & \multirow{2}{*}{ magistrate Dimitrii Ralet } & \multirow{2}{*}{$\begin{array}{l}\text { sardar Gheorghii } \\
\text { Leondari }\end{array}$} \\
\hline 112 & a part of Giulești & & & \\
\hline 113 & Telineștii & \multirow{2}{*}{ the region of Orheiu } & \multirow{2}{*}{ nun Zamfira Scorțasca } & \multirow{2}{*}{$\begin{array}{l}\text { collector of duties on } \\
\text { spirits Panaite Cazimir }\end{array}$} \\
\hline 114 & $\begin{array}{l}\text { Dumeștii, also called } \\
\text { Ghermanca }\end{array}$ & & & \\
\hline 115 & Vărticăuții & \multirow{4}{*}{ the region of Hotin } & \multirow{4}{*}{$\begin{array}{l}\text { sardar Alexandru } \\
\text { Anastasiu }\end{array}$} & \multirow{4}{*}{$\begin{array}{l}\text { same, collector of duties } \\
\text { on spirits Panaite } \\
\text { Cazimir }\end{array}$} \\
\hline 116 & Dresîții ${ }^{33}$ & & & \\
\hline 117 & Solonețul & & & \\
\hline 118 & Mihălășăni & & & \\
\hline 119 & Vădenii & \multirow{2}{*}{$\begin{array}{l}\text { the region of Orhei or } \\
\text { Lăpușna }\end{array}$} & \multirow{2}{*}{ same sardar Anastasiu } & \\
\hline 120 & Hudicenii & & & \\
\hline 121 & Mărteștii, parts & \multirow{4}{*}{$\begin{array}{l}\text { in the region of Orhei } \\
\text { and Iași }\end{array}$} & \multirow{4}{*}{ ban Toader Carp } & \multirow{4}{*}{$\begin{array}{l}\text { collector of duties on } \\
\text { spirits Panaite Cazimir }\end{array}$} \\
\hline 122 & Grebleștii, parts & & & \\
\hline 123 & Ghireștii, parts & & & \\
\hline 124 & Mirceștii, parts & & & \\
\hline 125 & Vrăneștii & \multirow{2}{*}{ in the region of Orhei } & \multirow{2}{*}{$\begin{array}{l}\text { caminar's wife Zoița } \\
\text { Carp }\end{array}$} & \multirow{2}{*}{ also to Cazimir } \\
\hline 126 & a part of Onteni & & & \\
\hline 127 & a part of Galbăna & & same & \\
\hline 128 & Vătejăni & \multirow{2}{*}{ in the region of Soroca } & \multirow{2}{*}{$\begin{array}{l}\text { collector of duties on } \\
\text { spirits Costandin Carp }\end{array}$} & come to Corimir \\
\hline 129 & Năpadova & & & same, to Cazimir \\
\hline 130 & $\begin{array}{l}\text { a part of the estate of } \\
\text { Chetroasa, the region of } \\
\text { Orhei }\end{array}$ & & same & same \\
\hline 131 & Levinții & & & \\
\hline 132 & $\begin{array}{l}\text { half of the estate of } \\
\text { Balamutca }\end{array}$ & the region of Hotin & $\begin{array}{l}\text { chancellor lordachi } \\
\text { Canta }\end{array}$ & chamberlain Alecu Ghica \\
\hline 133 & the $4^{\text {th }}$ part of Tribisăuți & & & \\
\hline 134 & Cărlăcău & the reoion of Hotin & spatharus Alexandru & Yosili Pocet \\
\hline 135 & Romancăuți & the region of Hotın & Ghica & Vasilı Roset \\
\hline 136 & $\begin{array}{l}\text { Salișca }^{34} \text {, in the region of } \\
\text { Hotin }\end{array}$ & & & \\
\hline 137 & the $3^{\text {rd }}$ part of Dănceni & & & \\
\hline 138 & the $3^{\text {rd }}$ part of Dulițeni & in the region of Orhei & colonel Panaite Docan & Vasili Roset \\
\hline 139 & the $3^{\text {rd }}$ part of Ulmeni & & & \\
\hline 140 & Vărnăuții & & & \\
\hline 141 & Vășcouții & the region of Hotin & & \\
\hline 142 & half of Bîrlănești & & magistrate s wife Loița & high steward Matei \\
\hline 143 & $\begin{array}{l}\text { Izvoarăle and Lozăni, } \\
\text { the region of Soroca }\end{array}$ & & & \\
\hline
\end{tabular}

\footnotetext{
${ }^{32}$ Or "Costuleni".

${ }^{33}$ Maybe: „Drevcăuți”.

${ }^{34}$ Probably: „Seliște”.
} 


\begin{tabular}{|c|c|c|c|c|}
\hline 144 & $\begin{array}{l}\text { Perisăcina, the region of } \\
\text { Orhei }\end{array}$ & & & \\
\hline 145 & Tătărășăni & \multirow{2}{*}{ the region of Codru } & \multirow{2}{*}{$\begin{array}{l}\text { sardar's wife Ilinca } \\
\text { Cantioai }\end{array}$} & \\
\hline 146 & Bosîncenii & & & \\
\hline 147 & Șărpenii & \multirow{2}{*}{ the region of Orhei } & \multirow{2}{*}{ spatharus Iordachi Ghica } & \multirow{2}{*}{ Rucsanda Sturzoai } \\
\hline 148 & Pugăcenii & & & \\
\hline 149 & $\begin{array}{l}\text { Bîrnova and Cot(ul) } \\
\text { Soroca, the region of } \\
\text { Hotin }\end{array}$ & & aga Alecu Ghica & $\begin{array}{l}\text { the merchant from } \\
\text { Odesa, second rank, } \\
\text { Coțovschii }\end{array}$ \\
\hline 150 & Măndăcăuții & \multirow{2}{*}{ the region of Hotin } & \multirow{2}{*}{ sardar Manolachi Radu } & \multirow{2}{*}{ captain Iancul Radul } \\
\hline 151 & a $6^{\text {th }}$ part of Hădărăuți & & & \\
\hline 152 & $\begin{array}{l}\text { Vărtăporul }{ }^{35}, \text { in the } \\
\text { region of Hotin }\end{array}$ & & $\begin{array}{l}\text { collector of duties on } \\
\text { spirits Costandin Negre }\end{array}$ & $\begin{array}{l}\text { collector of duties on } \\
\text { spirits Panaite Cazimir }\end{array}$ \\
\hline 153 & a part of Cornești & \multirow{2}{*}{ the region of Iași } & \multirow{2}{*}{$\begin{array}{l}\text { Marie, wife of Toader } \\
\text { Mărgărint }\end{array}$} & \multirow[b]{2}{*}{ Iordachi Bantăş } \\
\hline 154 & a part of Coștoroh ${ }^{36}$ & & & \\
\hline 155 & Tîrnova & \multirow{2}{*}{ the region of Soroca } & \multirow{2}{*}{ Grigori Cugureni $^{37}$} & \multirow{2}{*}{ Ion Crâste } \\
\hline 156 & half of Briceva & & & \\
\hline 157 & $\begin{array}{l}473 \text { meters of Siliști, in } \\
\text { the region of Iași }\end{array}$ & & $\begin{array}{l}\text { collector of duties on } \\
\text { spirits Anastasii } \\
\text { Scorțăscu }\end{array}$ & $\begin{array}{l}\text { collector of duties on } \\
\text { spirits Zamfirache Rale }\end{array}$ \\
\hline 158 & a part of Vărzărești & \multirow{2}{*}{ the region of Orhei } & \multirow{2}{*}{$\begin{array}{l}\text { the vestrymen of boyar } \\
\text { Conachi }\end{array}$} & \multirow{2}{*}{ same, Zamfirachi } \\
\hline 159 & half of Hoginești & & & \\
\hline 160 & $\begin{array}{l}\text { Sirota, the region of } \\
\text { Orhei }\end{array}$ & & ban Iordachi Drăghici & Zoe Dimitriu \\
\hline 161 & Bodeștii & & & \\
\hline 162 & $\begin{array}{l}\text { the } 3^{\text {rd }} \text { part of Zhorna, } \\
\text { the region of Soroca }\end{array}$ & & same, Drăghici & $\begin{array}{l}\text { lord steward Costachi } \\
\text { Bucșănescu }\end{array}$ \\
\hline 163 & Gîndeștii & \multirow{4}{*}{ the region of Codru } & \multirow{4}{*}{$\begin{array}{l}\text { magistrate's wife Zoița } \\
\text { Balș }\end{array}$} & \multirow{4}{*}{ Vasili Crâste } \\
\hline 164 & Buciumeni & & & \\
\hline 165 & Cordeşîia & & & \\
\hline 166 & the $3^{\text {rd }}$ part of Toceni & & & \\
\hline 167 & $\begin{array}{l}\text { Cosăuții, in the region of } \\
\text { Soroca }\end{array}$ & & \multirow[t]{2}{*}{$\begin{array}{l}\text { spatharus's wife } \\
\text { Prihirița }^{38} \text { Cantacozino }\end{array}$} & \multirow[t]{2}{*}{ comis Alexandru Panaite } \\
\hline 168 & $\begin{array}{l}\text { Teșcureni, in the region } \\
\text { of Iași }\end{array}$ & & & \\
\hline 169 & Tîrgu Leova & \multirow{9}{*}{$\begin{array}{l}\text { in the region of Codru } \\
\text { and }{ }^{39} \text { Greceni. Apart } \\
\text { from these villages and } \\
\text { village places in the area } \\
\text { called Doî Ceasuri }\end{array}$} & \multirow{9}{*}{$\begin{array}{l}\text { chancellor Costachi } \\
\text { Ghica }\end{array}$} & \multirow{9}{*}{ spatharus Ioan Sturza } \\
\hline 170 & Măldărenii & & & \\
\hline 171 & Bebenii & & & \\
\hline 172 & Bujorul & & & \\
\hline 173 & Băzhanii $^{40}$ & & & \\
\hline 174 & Meșănii & & & \\
\hline 175 & Surducul & & & \\
\hline 176 & Horanevul & & & \\
\hline 177 & Mirceștii & & & \\
\hline 178 & Cepălăuții & \multirow{5}{*}{ in the region of Hotin } & \multirow{5}{*}{ still Ghica } & \\
\hline 179 & Hancăuții & & & \\
\hline 180 & Anadolul & & & still Sturzii \\
\hline 181 & Vorhotinul $^{41}$ & & & \\
\hline 182 & Mihalcăuții & & & \\
\hline
\end{tabular}

\footnotetext{
${ }^{35}$ Probably: „Vertep”.

${ }^{36}$ Original version.

${ }^{37}$ Probably: „Ciuhureanu”.

${ }^{38}$ Original version, for: "Prohirița”.

${ }^{39}$ Slavicism: "and".

${ }^{40}$ Original version.

${ }^{41}$ Original version.
} 


\begin{tabular}{|c|c|c|c|c|}
\hline 183 & Bușăvca ${ }^{42}$ & the rovion of $\Omega$ rbi & chancellor Costachi & \\
\hline 184 & Ghidulenii & the region of Urhe1 & Ghica & spatharus Ioan Sturza \\
\hline 185 & $\begin{array}{l}\text { Tășcureni, in the region } \\
\text { of Iași }\end{array}$ & & comis Alexandru Panaite & Gheorghii Storianu \\
\hline 186 & $\begin{array}{l}\text { a part of Tocsobeni, the } \\
\text { region of Iaşi }\end{array}$ & & $\begin{array}{l}\text { Cerchez clerk } \\
\text { administrator }\end{array}$ & Gheorghii Sorocianu \\
\hline 187 & a part of Trifești & \multirow{7}{*}{ in the region of Soroca } & \multirow{7}{*}{ pitar Gheorghii Sorocian } & \multirow{7}{*}{$\begin{array}{l}\text { Grigori and Costandin, } \\
\text { Soroceni }\end{array}$} \\
\hline 188 & a part of Mirceni & & & \\
\hline 189 & a part of Cozmeni & & & \\
\hline 190 & a part of Zăloboteni ${ }^{43}$ & & & \\
\hline 191 & a part of Fore & & & \\
\hline 192 & a part of Bocşilă & & & \\
\hline 193 & a part of Marcăuți & & & \\
\hline 194 & $\begin{array}{l}473 \text { meters of Pojorăni, } \\
\text { the region of Orhei }\end{array}$ & & $\begin{array}{l}\text { chancellor's wife Ilinca } \\
\text { Păladi and comis } \\
\text { Costandin Bogdan }\end{array}$ & $\begin{array}{l}\text { Ioniță and Toader, } \\
\text { Surucenii }\end{array}$ \\
\hline 195 & $\begin{array}{l}\text { the } 3^{\text {rd }} \text { part of Păşcăuți, } \\
\text { in the region of Iași }\end{array}$ & & șătrar Ștefan Stârce & captain Irimie Ciuhurean \\
\hline 196 & Ezărenii & \multirow{4}{*}{ in the region of Iaşi } & \multirow{4}{*}{ ban Alexandru Beldiman } & \multirow{4}{*}{ Matei Panaite } \\
\hline 197 & Berheciul & & & \\
\hline 198 & Coretaneștii & & & \\
\hline 199 & several parts of Roșcani & & & \\
\hline 200 & Sanja & \multirow{2}{*}{ the region of Soroca } & \multirow{2}{*}{ Grigorii Başotă } & \multirow{2}{*}{ high steward Ion Bantăș } \\
\hline 201 & Cucueții & & & \\
\hline 202 & Căzăneștii & \multirow{2}{*}{ the region of Orhei } & the vestrymen of the year & \multirow{2}{*}{ major Șăinovici $^{44}$} \\
\hline 203 & a part of Cetilova & & Costachi Sturza & \\
\hline 204 & $\begin{array}{l}\text { Vărdeșăni, in the region } \\
\text { of Codru }^{45}\end{array}$ & & Petre Rosăt & Vasile Rosăt \\
\hline 205 & Ţiganca & \multirow{2}{*}{ in the region of Orhei } & high steward Ion & \multirow{2}{*}{$\begin{array}{l}\text { collector of duties on } \\
\text { spirits Panaite Cazimir }\end{array}$} \\
\hline 206 & Negreleștii & & Costachi & \\
\hline 207 & $\begin{array}{l}\text { Ocnița, in the region of } \\
\text { Hotin }\end{array}$ & & & \\
\hline 208 & $\begin{array}{l}\text { half of Bălți in the region } \\
\text { of Soroca }\end{array}$ & & comis Costachi Sturza & $\begin{array}{l}\text { collector of duties on } \\
\text { spirits Pruncu }\end{array}$ \\
\hline 209 & Chelmeștii & \multirow{4}{*}{ the region of Hotin } & \multirow{4}{*}{ treasurer Iordache Roset } & \multirow{4}{*}{$\begin{array}{l}\text { collector of duties on } \\
\text { spirits Panaite Cazimir }\end{array}$} \\
\hline 210 & Mușinețul & & & \\
\hline 211 & $\begin{array}{l}\text { a } 10^{\text {th }} \text { part of the } 24^{\text {th }} \\
\text { part of Cruhlic }\end{array}$ & & & \\
\hline 212 & the $4^{\text {th }}$ part of Singereni & & & \\
\hline 213 & Vădenii & \multirow{2}{*}{ in the region of Soroca } & \multirow{7}{*}{ hetman Sandul Sturza } & \multirow{7}{*}{ Panaite Cazimir } \\
\hline 214 & Tăbărceni & & & \\
\hline 215 & Costănelu & \multirow{2}{*}{ the region of Iași } & & \\
\hline 216 & Zabulenii & & & \\
\hline 217 & Zăhăicani & \multirow{3}{*}{ the region of Orhei } & & \\
\hline 218 & Tîrzieni & & & \\
\hline 219 & $\begin{array}{l}\text { Braviceni, more than a } \\
\text { half }\end{array}$ & & & \\
\hline 220 & $\begin{array}{l}\text { Nilipăuții, in the region } \\
\text { of Hotin }\end{array}$ & & ban Dumitru Beldiman & spatharus Ioan Sturza \\
\hline 221 & Cotujăni & \multirow{2}{*}{ the region of Soroca } & spatharus's wife Rucsanda & \multirow{2}{*}{ Gheorghii Dimitriu } \\
\hline 222 & Bejăica $^{46}$ & & Roset & \\
\hline
\end{tabular}

\footnotetext{
42 "Buşăuca”.

43 "Zăboloteni”.

${ }^{44}$ Uncertain reading.

${ }^{45}$ The words "to Răut" are next, but they have been hatched.

${ }^{46}$ Uncertain reading.
} 


\begin{tabular}{|c|c|c|c|c|}
\hline 223 & Verjî̀ca $^{47}$ & \multirow{3}{*}{ in the region of Hotin } & \multirow{4}{*}{$\begin{array}{l}\text { collector of duties on } \\
\text { spirits Mihalachi }\end{array}$} & \multirow{4}{*}{$\begin{array}{l}\text { collector of duties on } \\
\text { spirits Zamfirachi Rale }\end{array}$} \\
\hline 224 & Bobena & & & \\
\hline 225 & Vălcinețu & & & \\
\hline 226 & $\begin{array}{l}150 \text { meters of Trășteni } \\
\text { in the region of Iași }\end{array}$ & & & \\
\hline 227 & $\begin{array}{l}62 \text { meters of Iazoviți and } \\
2 \text { meters of Tocsobeni }\end{array}$ & \multirow[t]{2}{*}{ the region of Iași } & \multirow[t]{2}{*}{$\begin{array}{l}\text { Nastasie Ciorniiasa } \\
\text { Gheorghii Heciulă }{ }^{49}\end{array}$} & \multirow[t]{2}{*}{$\begin{array}{l}\text { chamberlain Vasile Cujbă } \\
\text { same, Cujbă }\end{array}$} \\
\hline 228 & o parte din Onteni ${ }^{50}$ & & & \\
\hline 229 & Bărbănăuții & \multirow{4}{*}{ a part of those in Hotin } & \multirow{4}{*}{ Ion Ghițăscu } & \multirow{4}{*}{$\begin{array}{l}\text { Ioniță the treasury } \\
\text { employee }\end{array}$} \\
\hline 230 & Medveja & & & \\
\hline 231 & Cotăjini $^{51}$ & & & \\
\hline 232 & Hădărăuții & & & \\
\hline 233 & $\begin{array}{l}\text { the fourth part of the } 4^{\text {th }} \\
\text { part of the estate of } \\
\text { Stroeștii }\end{array}$ & \multirow[t]{2}{*}{ the region of Hotin } & \multirow[t]{2}{*}{$\begin{array}{l}\text { lord steward Ștefan and } \\
\text { Ilii, Holbănești }\end{array}$} & \multirow[t]{2}{*}{$\begin{array}{l}\text { the Austrian subject } \\
\text { Costandin Morțun }\end{array}$} \\
\hline 234 & $\begin{array}{l}\text { a fourth part of } \\
\text { Costuleni }\end{array}$ & & & \\
\hline 235 & $\begin{array}{l}\text { Putineștii, in the region } \\
\text { of Soroca }\end{array}$ & & $\begin{array}{l}\text { spatharus Neculai } \\
\text { Dimachi }\end{array}$ & Iordachi Donici \\
\hline 236 & $\begin{array}{l}\text { Voloşnicău, in the region } \\
\text { of Soroca }\end{array}$ & & Zoița Cuzoai & $\begin{array}{l}\text { the merchant from } \\
\text { Odesa, } 2^{\text {nd }} \text { rank, } \\
\text { Cuțovschii }\end{array}$ \\
\hline 237 & Negrinţii & \multirow{8}{*}{ the region of Hotin } & \multirow{8}{*}{$\begin{array}{l}\text { collector of duties on } \\
\text { spirits Ciure }\end{array}$} & \multirow{8}{*}{ his son } \\
\hline 238 & Horelcăuți & & & \\
\hline 239 & Criva & & & \\
\hline 240 & Nisfoaia & & & \\
\hline 241 & Şărcanii & & & \\
\hline 242 & half of Zălina & & & \\
\hline 243 & $\begin{array}{l}\text { half of the } 16^{\text {th }} \text { part of } \\
\text { Zaluceni }\end{array}$ & & & \\
\hline 244 & $\begin{array}{l}3 \text { parts of the } 4^{\text {th }} \text { part of } \\
\text { Pecicul }\end{array}$ & & & \\
\hline 245 & $\begin{array}{l}\text { half of the } 12^{\text {th }} \text { part of } \\
\text { Costiceni }\end{array}$ & & & \\
\hline 246 & half of Dumeni & \multirow{10}{*}{ the region of Hotin } & \multirow{10}{*}{$\begin{array}{l}\text { Tudurachi Ciure, } \\
\text { pursuant to the will }\end{array}$} & \multirow{10}{*}{ Costandin } \\
\hline 247 & half of Șăndreni & & & \\
\hline 248 & half of Mușineț & & & \\
\hline 249 & $\begin{array}{l}\text { the third of a } 4^{\text {th }} \text { part of } \\
\text { Cotela }\end{array}$ & & & \\
\hline 250 & $\begin{array}{l}\text { half and a } 6^{\text {th }} \text { part of } \\
\text { Solonețcu }\end{array}$ & & & \\
\hline 251 & $\begin{array}{l}\text { the fourth part of the } 8^{\text {th }} \\
\text { part of Meleteuți }\end{array}$ & & & \\
\hline 252 & a third of Colincăuți & & & \\
\hline 253 & a third of Șișcăuți & & & \\
\hline 254 & a third of Boșcani & & & \\
\hline 255 & a fourth part of Medveja & & & \\
\hline 256 & Bogdăneștii & \multirow{3}{*}{ in the region of Iași } & \multirow{3}{*}{ magistrate Grigori Ghica } & \multirow{3}{*}{$\begin{array}{l}\text { chamberlain Alexandru } \\
\text { Ghica }\end{array}$} \\
\hline 257 & Huhurez & & & \\
\hline 258 & Malinița ${ }^{52}$, Hotin & & & \\
\hline
\end{tabular}

\footnotetext{
${ }^{47}$ Uncertain reading.

48 “Trăisteni”.

${ }^{49}$ Uncertain reading.

${ }^{50}$ Followed by "the region of Iași", then hatched.

51 „Cotiujăni”.

52 „Malinți”.
} 


\begin{tabular}{|c|c|c|c|c|}
\hline 259 & $\begin{array}{l}\text { Zarujăni, the region of } \\
\text { Hotin }\end{array}$ & & \multirow[t]{2}{*}{$\begin{array}{l}\text { the magistrate Neculai } \\
\text { Strătulat }\end{array}$} & \multirow[t]{2}{*}{ Dumitru Iani } \\
\hline 260 & $\begin{array}{l}\text { Cozăicu }{ }^{53} \text {, the region of } \\
\text { Orhei }\end{array}$ & & & \\
\hline 261 & Duneștii & \multirow{2}{*}{ in the region of Iași } & \multirow{2}{*}{$\begin{array}{l}\text { collector of duties on } \\
\text { spirits Andrei Bașotă }\end{array}$} & \multirow{2}{*}{$\begin{array}{l}\text { cupbearer Toma Stamate } \\
\text { and medelnicer Andrieș }\end{array}$} \\
\hline 262 & a part of Teșăni & & & \\
\hline 263 & Ohrince & \multirow{2}{*}{ the region of Orhei } & \multirow{3}{*}{ sărdar Grigori Codreanu } & \multirow{3}{*}{$\begin{array}{l}\text { collector of duties on } \\
\text { spirits Panaite Cazimir }\end{array}$} \\
\hline 264 & Drăicenii & & & \\
\hline 265 & $\begin{array}{l}\text { Iucanii }{ }^{54} \text {, the region of } \\
\text { Codru }\end{array}$ & & & \\
\hline 266 & $\begin{array}{l}\text { the fourth part of } \\
\text { Paustova, the region of } \\
\text { Hotin }\end{array}$ & & lord steward Vasili Docan & Iordachi Bantăş \\
\hline 267 & $\begin{array}{l}\text { a part of Albeștiot } \\
\text { Orheiu }\end{array}$ & & Iliana Bățoae & Stamati Bățu \\
\hline 268 & Bîrnova & \multirow{4}{*}{ the region of Hotin } & \multirow{4}{*}{ spatharus Grigori Balș } & \multirow{4}{*}{$\begin{array}{l}\text { collector of duties on } \\
\text { spirits Panaite Cazimir }\end{array}$} \\
\hline 269 & Pernăuții & & & \\
\hline 270 & Beșenăuții & & & \\
\hline 271 & half of Lopatinți & & & \\
\hline 272 & $\begin{array}{l}\text { Trăistei, also called Plop, } \\
\text { the region of Soroca }\end{array}$ & & spatharus Petrachi Sturza & Spiridon Dimitriu \\
\hline 273 & Mălăeștii & \multirow{4}{*}{ the region of Orhei } & \multirow{3}{*}{ Iordachi Foti } & \multirow{3}{*}{$\begin{array}{l}\text { medelnicer Ioniță } \\
\text { Nemișăscu }\end{array}$} \\
\hline 274 & Tudurcenii & & & \\
\hline 275 & Neceștui & & & \\
\hline 276 & $\begin{array}{l}\text { a part of Cuizăuca, the } \\
\text { region of Orhei }\end{array}$ & & $\begin{array}{l}\text { comis Alexandru } \\
\text { Hrisoverghi }\end{array}$ & same, Nemişăscu \\
\hline 277 & Socii & \multirow{3}{*}{ the region of Iași } & \multirow{3}{*}{$\begin{array}{l}\text { sărdar Costandin } \\
\text { Burghele }\end{array}$} & \multirow{3}{*}{$\begin{array}{l}\text { medelnicer Gheorghii } \\
\text { Dimitriu }\end{array}$} \\
\hline 278 & a sixth of Bozieni & & & \\
\hline 279 & a sixth of Răd(iu) Mari & & & \\
\hline 280 & $\begin{array}{l}\text { Aluru, the region of } \\
\text { Codru }\end{array}$ & & spatharus Grigorii Cuza & Neculai Milu \\
\hline 281 & Taracauții & \multirow{2}{*}{ the region of Iași } & \multirow{2}{*}{$\begin{array}{l}\text { spatharus Costandin } \\
\text { Roset }\end{array}$} & \multirow{2}{*}{ spatharus Ioan Sturza } \\
\hline 282 & Măgura & & & \\
\hline 283 & Tilișăuca & \multirow{2}{*}{ the region of Soroca } & \multirow{2}{*}{ căminar Vasili Balș } & \multirow{2}{*}{$\begin{array}{l}\text { cupbearer Stamati and } \\
\text { medelnicer Andrieș }\end{array}$} \\
\hline 284 & Veșca & & & \\
\hline 285 & $\begin{array}{l}\text { Borosănii, the region of } \\
\text { Soroca }\end{array}$ & & ban Ștefan Bașotă & same, the aforementioned \\
\hline 286 & Corneștii & \multirow{2}{*}{ the region of Iaşi } & high steward's wife Marie & \multirow{2}{*}{ merchant Capşa } \\
\hline 287 & a part of Cozmeni & & Holbăniasa & \\
\hline 288 & $\begin{array}{l}\text { Vascăuții, the region of } \\
\text { Orhei }\end{array}$ & & Toader Silion & $\begin{array}{l}\text { cupbearer Stamate and } \\
\text { Andrieș }\end{array}$ \\
\hline 289 & $\begin{array}{l}\text { Cogîlniceni, the region } \\
\text { of Orhei }\end{array}$ & & $\begin{array}{l}\text { the vestrymen of the } \\
\text { daughter of Manolachi } \\
\text { Bals }\end{array}$ & merchant Ion Hărțăscu \\
\hline 290 & $\begin{array}{l}\text { the fourth part of } \\
\text { Alcidar }\end{array}$ & \multirow[t]{2}{*}{ the region of Soroca } & \multirow[t]{2}{*}{$\begin{array}{l}\text { high steward Costandin } \\
\text { Manoli }\end{array}$} & $\begin{array}{l}\text { medelnicer Manolachi } \\
\text { Andrieș }\end{array}$ \\
\hline 291 & $\begin{array}{l}\text { the fourth part of } \\
\text { Leșciasa }\end{array}$ & & & \\
\hline 292 & Cocliia & & & \\
\hline 293 & Half of Răulele & the region of Codru & cupbearer Alecu Afenduli & sardar Vartolomei \\
\hline 294 & half of Ruptura Mare & & & \\
\hline 295 & Blîndenii & the region of $O$ rhei & & \\
\hline 296 & half of Scurtești & the region of Urnes & & \\
\hline 297 & a part of Lămășăni & & & \\
\hline 298 & a part of Dușăni & the region of Hotin & & \\
\hline
\end{tabular}

53 "Cuizăuca”.

${ }^{54}$ Original version. 


\begin{tabular}{|c|c|c|c|c|}
\hline 299 & a part of Pătrăuți & & \multirow{6}{*}{$\begin{array}{l}\text { Costandin Bantăș and } \\
\text { spatharus's wife Marie } \\
\text { Costache }\end{array}$} & \multirow{6}{*}{$\begin{array}{l}\text { Iordachi Bantăș and } \\
\text { spatharus Ioan Sturza }\end{array}$} \\
\hline 300 & a part of Căfieni & & & \\
\hline 301 & Brînzănii & \multirow{4}{*}{ the region of Soroca } & & \\
\hline 302 & Perienii & & & \\
\hline 303 & Climăuții & & & \\
\hline 304 & Horodiște & & & \\
\hline 305 & $\begin{array}{l}\text { Sinesul }{ }^{55} \text {, the region of } \\
\text { Hotin }\end{array}$ & & treasurer Sandul Sturza & $\begin{array}{l}\text { collector of duties on } \\
\text { spirits Panaite Cazimir }\end{array}$ \\
\hline 306 & $\begin{array}{l}\text { the fourth part of } \\
\text { Mașcăuți, the region of } \\
\text { Soroca }\end{array}$ & & $\begin{array}{l}\text { lord steward Tudurachi } \\
\text { Ciure }\end{array}$ & his sister, Casandrii \\
\hline 307 & $\begin{array}{l}\text { Cioropcani, half, the } \\
\text { region of Iași }\end{array}$ & & the vestrymen D. Muruz & Ilii Buzne \\
\hline 308 & half of Cosăești & \multirow{2}{*}{ the region of Hotin } & \multirow{2}{*}{ ban Arghirii Cuza } & \multirow{2}{*}{ Iancu Dimitriu } \\
\hline 309 & Ghermăzănii & & & \\
\hline 310 & $\begin{array}{l}\text { Cupcinu, the region of } \\
\text { Hotin }\end{array}$ & & $\begin{array}{l}\text { ban Gheorghii and } \\
\text { Toader Buhuș }\end{array}$ & Costachi Popov \\
\hline 311 & $\begin{array}{l}\text { Sărata, the region of } \\
\text { Orheiului }\end{array}$ & & the vestrymen D. Muruz & Vasili Iamandi \\
\hline 312 & Pravila & \multirow{2}{*}{ the region of Soroca } & same, the vestrymen D. & \multirow{2}{*}{ Gheorghii Meleli $^{56}$} \\
\hline 313 & Vădurelile & & Muruz & \\
\hline 314 & $\begin{array}{l}\text { Lăncăuții, the region of } \\
\text { Soroca }\end{array}$ & & $\begin{array}{l}\text { same, the vestrymen D. } \\
\text { Muruz }\end{array}$ & Vasili Pușcă \\
\hline 315 & $\begin{array}{l}\text { small town of Telineștii, } \\
\text { the region of Orhei }\end{array}$ & & same, the vestrymen & pitar Teodosii \\
\hline 316 & $\begin{array}{l}\text { Bogdăneștii, the region } \\
\text { of Iașului }\end{array}$ & & $\begin{array}{l}\text { sulger's wife Marie } \\
\text { Năstasi }\end{array}$ & Panaite Cazimir \\
\hline 317 & $\begin{array}{l}\text { Crimenciuc, the region } \\
\text { of Soroca }\end{array}$ & & \multirow[t]{2}{*}{$\begin{array}{l}\text { high steward Iordachi } \\
\text { Murguleț }\end{array}$} & \multirow[t]{2}{*}{ his son, Vasili } \\
\hline 318 & $\begin{array}{l}\text { the third of half of } \\
\text { Stroești, the region of } \\
\text { Hotin }\end{array}$ & & & \\
\hline 319 & $\begin{array}{l}\text { Unienii }^{57} \text {, the region of } \\
\text { Iași Iașului }\end{array}$ & & Iliana Carage & comis Alexandru Negre \\
\hline 320 & $\begin{array}{l}\text { Tintenii, the region of } \\
\text { Greceni }\end{array}$ & & $\begin{array}{l}\text { sărdar's wife Iliana } \\
\text { Cantacuzino }\end{array}$ & comis Iancul Balș ${ }^{58}$ \\
\hline 321 & $\begin{array}{l}\text { the third of } 5 \text { original } \\
\text { estates (bătrîni) of } \\
\text { Onteni, the region of Iași }\end{array}$ & & Zamfira Cujboai & chamberlain Vasili Cujbă \\
\hline 322 & $\begin{array}{l}\text { Izbește, the region of } \\
\text { Orhei }\end{array}$ & & $\begin{array}{l}\text { magistrate Costandin } \\
\text { Balț }\end{array}$ & $\begin{array}{l}\text { magistrate Costandin } \\
\text { Păladi }\end{array}$ \\
\hline 323 & $\begin{array}{l}\text { half of Paustova, the } \\
\text { region of Hotin }\end{array}$ & & lord steward Vasili Docan & same Păladi \\
\hline 324 & Boșcana, half & \multirow{4}{*}{ the region of Hotinului } & \multirow{4}{*}{$\begin{array}{l}\text { sulger's wife Marie } \\
\text { Brănoai }\end{array}$} & \multirow{4}{*}{ cupbearer Toma Stamate } \\
\hline 325 & Vertepul, half & & & \\
\hline 326 & Ringaciul, half & & & \\
\hline 327 & $\begin{array}{l}\text { Șălăuții, without a } 4^{\text {th }} \\
\text { part }\end{array}$ & & & \\
\hline 328 & Cunice & \multirow{2}{*}{ the region of Soroca } & \multirow{2}{*}{ Safta Costinoai } & \multirow{2}{*}{ pitar Teodosii } \\
\hline 329 & a part of Hăsnășăni & & & \\
\hline 330 & $\begin{array}{l}\text { Corneștii, the region of } \\
\text { Hotin }\end{array}$ & & hetman Răducanu Roset & comis Iancul Balș \\
\hline
\end{tabular}

\footnotetext{
${ }^{55}$ Original version.

${ }^{56}$ Probably: "Meleghi”.

${ }^{57}$ Probably: "Unghenii".

${ }^{58}$ Name written and then hatched.
} 


\begin{tabular}{|c|c|c|c|c|}
\hline 331 & $\begin{array}{l}\text { half of Frăsinești, the } \\
\text { region of Iași }\end{array}$ & & & \\
\hline 332 & Drăgușăștii & \multirow{10}{*}{ the region of Iaşi } & \multirow{10}{*}{ magistrate Alecu Balș } & \multirow{10}{*}{ comis Iancul Balș } \\
\hline 333 & Zberoai & & & \\
\hline 334 & Piceștii & & & \\
\hline 335 & small town of Pînzăreni & & & \\
\hline 336 & Pînzărenii Vechi & & & \\
\hline 337 & Sfrejănii & & & \\
\hline 338 & Ifrimeștiii & & & \\
\hline 339 & a part of Bîlcurești & & & \\
\hline 340 & Vale Ranhului & & & \\
\hline 341 & Bălăniali" & & & \\
\hline 342 & $\begin{array}{l}\text { Pogoneștii, the region of } \\
\text { Hotin }\end{array}$ & & \multirow{4}{*}{ treasurer Alecu Balș } & \multirow{4}{*}{ comis Iancul Balş } \\
\hline 343 & Corbul & \multirow{3}{*}{ the region of Soroca } & & \\
\hline 344 & Ciornoleuca & & & \\
\hline 345 & Andrieșăni & & & \\
\hline 346 & $\begin{array}{l}\text { Vovătenii, with other } \\
\text { parts, the region of } \\
\text { Hotin }\end{array}$ & & medelnicer Tănase Feștilă & Vasile Crâste \\
\hline 347 & $\begin{array}{l}\text { a part of Florenți, the } \\
\text { region of Iași }\end{array}$ & & Ion Bosii & sulger Pascal Tudori \\
\hline 348 & $\begin{array}{l}\text { of Trifessti and Frumoasa, } \\
\text { a part of each }\end{array}$ & \multirow[t]{2}{*}{ the region of Greceni } & \multirow[t]{2}{*}{$\begin{array}{l}\text { spatharus Neculai } \\
\text { Hrisoverghi }\end{array}$} & \multirow[t]{2}{*}{ comis Iancul Balș } \\
\hline 349 & a sixth of Găunițăni ${ }^{60}$ & & & \\
\hline 350 & $\begin{array}{l}\text { half of Hîrjăuți, the } \\
\text { region of Hotin }\end{array}$ & & $\begin{array}{l}\text { medelnicer's wife Marie } \\
\text { Feștiloai }\end{array}$ & $\begin{array}{l}\text { collector of duties on } \\
\text { spirits Zamfirache Rale }\end{array}$ \\
\hline 351 & half of Cotiujăni & \multirow{2}{*}{ the region of Hotin } & \multirow{2}{*}{ Darii administrator } & \multirow{2}{*}{ sovednic Teodosiu } \\
\hline 352 & half of Bosieni & & & \\
\hline 353 & Verejăni & \multirow{3}{*}{ the region of Orhei } & \multirow{3}{*}{ Marie Irimieva } & \multirow{3}{*}{ same Teodosiu } \\
\hline 354 & Vărzăreștii & & & \\
\hline 355 & Bodurcenii & & & \\
\hline 356 & $\begin{array}{l}\text { Cerbiceni, half, the } \\
\text { region of Hotin }\end{array}$ & & $\begin{array}{l}\text { cupbearer's wife Marie } \\
\text { Micliasca }\end{array}$ & same Teodosiu \\
\hline 357 & $\begin{array}{l}\text { Șărăuții, the region of } \\
\text { Hotin }\end{array}$ & & $\begin{array}{l}\text { lord steward Dinu, } \\
\text { Gheorghii and Enachi, }\end{array}$ & Manolachi Negruți \\
\hline 358 & $\begin{array}{l}\text { Goteștii, the region of } \\
\text { Grecenii }\end{array}$ & & Negruțăști & \\
\hline 359 & Tohatinu & \multirow{4}{*}{ the region of Orhei } & \multirow{14}{*}{ ban Petrachi Cazimir } & \multirow{14}{*}{ caminar Panaite Cazimir } \\
\hline 360 & Mihuțăni & & & \\
\hline 361 & Vadul lui Vodă & & & \\
\hline 362 & Boșcana & & & \\
\hline 363 & $\begin{array}{l}\text { Stoicani, the region of } \\
\text { Soroca }\end{array}$ & & & \\
\hline 364 & Novosălița & \multirow{5}{*}{ the region of Hotin } & & \\
\hline 365 & Hropevna & & & \\
\hline 366 & a part Deinăuți & & & \\
\hline 367 & half of Rusăști & & & \\
\hline 368 & $\begin{array}{l}\text { a fourth part of } \\
\text { Nelipăuți }\end{array}$ & & & \\
\hline 369 & Săncăuții & & & \\
\hline 370 & the third of Cotiujăni & & & \\
\hline 371 & Berlinții & & & \\
\hline 372 & half of Gurmuzăni & & & \\
\hline
\end{tabular}

\footnotetext{
59 "Bălănești".

${ }^{60}$ Original version.
} 


\begin{tabular}{|c|c|c|c|c|}
\hline 373 & $\begin{array}{l}2 \text { parts of a } 5^{\text {th }} \text { of } \\
\text { Nisloveni and of } \\
\text { Copelova and of Cotela }\end{array}$ & & & \\
\hline 374 & Dolinenii & \multirow{7}{*}{ the region of Hotin } & \multirow{7}{*}{ magistrate Toader Balș } & \multirow{7}{*}{ comis Iancul Balș } \\
\hline 375 & Doljocu & & & \\
\hline 376 & a part of Trebujăni & & & \\
\hline 377 & 10 parts of Cruhlic & & & \\
\hline 378 & $\begin{array}{l}\text { a fourth part of } \\
\text { Sîngereni }\end{array}$ & & & \\
\hline 379 & 12 parts of Bălcăuți & & & \\
\hline 380 & $\begin{array}{l}\text { the fourth part of } \\
\text { Forosna }\end{array}$ & & & \\
\hline 381 & Silișăni & \multirow{5}{*}{ the region of Hotin } & \multirow{5}{*}{ treasurer Sandul Sturza } & \multirow{5}{*}{ comis Iancul Balș } \\
\hline 382 & Roșcanii & & & \\
\hline 383 & $\begin{array}{l}\text { a part of Cobusca de } \\
\text { Gios }\end{array}$ & & & \\
\hline 384 & a part of Luica de Sus & & & \\
\hline 385 & a part of Petreni & & & \\
\hline 386 & $\begin{array}{l}\text { a } 4^{\text {th }} \text { part of Drulești, } \\
\text { also called Săncăuți }\end{array}$ & & $\begin{array}{l}\text { collector of duties on } \\
\text { spirits Tudurachi Ciure }\end{array}$ & Casandra Ciudinoai \\
\hline 387 & $\begin{array}{l}\text { Negresstii, the region of } \\
\text { Orhei }\end{array}$ & & magistrate Șărban Negel & Mihai Hermeziu \\
\hline
\end{tabular}

